\title{
KRT17 wt Allele
}

National Cancer Institute

\section{Source}

National Cancer Institute. KRT17 wt Allele. NCI Thesaurus. Code C105978.

Human KRT 17 wild-type allele is located in the vicinity of $17 q 21.2$ and is approximately 5 $\mathrm{kb}$ in length. This allele, which encodes keratin, type I cytoskeletal 17 protein, is involved in the formation of hair follicles and sebaceous glands. Mutations in this gene are associated with Jackson-Lawler type pachyonychia congenita and steatocystoma multiplex. 